\title{
ISIS Menuju Asia Tenggara: Ancaman dan Kerja Sama Keamanan Kawasan dalam Menghadapi Peningkatan Ekspansi ISIS
}

\author{
Khoirul Amin \\ Jurusan IImu Hubungan Internasional \\ Universitas Muhammadiyah Kalimantan Timur \\ J. H. Juanda, Kota Samarinda, Kalimantan Timur 75243 \\ ka163@umkt.ac.id \\ Submitted: 18 January 2018, Accepted: 22 March 2018
}

\begin{abstract}
The Marawi war in early 2017 became the most explicit evidence of ISIS terrorist group existence in Southeast Asia. The region is pre dicted to be their new territory for expansion under the leadership of Abu Bakar Al-Baghdadi, even more after their lost at many territories in the Middle East. The Southeast Asia countries immediately generate preventive actions by strengthening the territorial security cooperation. This paper examines how Southeast Asia has great possibility to be the new destination for ISIS to invade and how the countries in Southeast Asia deal the threat. It is assumed that ISIS as part of global terrorism is trying to widen their expansion to Southeast Asia and how the countries in Southeast Asia rise up cooperation among them to prevent and resist from the ISIS expansion.

Keywords: ISIS threat, security cooperation, Southeast Asia Region.
\end{abstract}

\begin{abstract}
Abstrak
Pertempuran di Marawi pada awal tahun 2017 menjadi bukti paling jelas hadirnya ancaman kelompok teroris ISIS di kawasan Asia Tenggara. Asia Tenggara diprediksi menjadi tujuan baru bagi agenda perluasan wilayah kekhalifahan Negara Islam di bawah Abu Bakar AlBaghdadi setelah mengalami banyak kekalahan dan kehilangan wilayah kekuasaan di Timur Tengah. Negara-negara di Asia Tenggara segera mengambil langkah atraktif dengan meningkatkan kerja sama keamanan kawasan sebagai upaya sekuritisasi. Tulisan ini mengkaji bagaimana kawasan Asia Tenggara berpotensi besar menjadi tujuan baru bagi ISIS untuk kembali membangun kekuatan dan bagaimana upaya negaranegara di Asia Tenggara menghadapi ancaman tersebut. Tulisan ini berpendapat bahwa ISIS sebagai bagian dari terorisme global sedang berusaha memperluas pengaruhnya ke Asia Tenggara dan peningkatan kerja sama keamanan kawasan yang dilakukan negara-negara di Asia Tenggara, dapat dipahami sebagai bentuk upaya menghadapi ekspansi ISIS di kawasan.

Kata kunci: ancaman ISIS, kerja sama keamanan, kawasan Asia Tenggara.
\end{abstract}

\section{PENDAHULUAN}

Selama operasi militer masif yang terus dilancarkan oleh pasukan militer Irak dan Suriah maupun pasukan koalisi yang dipimpin Amerika Serikat di beberapa wilayah di Timur Tengah, Negara Islam Irak dan Syiria (ISIS) diyakini telah kehilangan basis-basis kekuatan penting di kawasan tersebut. Ini dibuktikan dengan keberhasilan koalisi pasukan militer negara-negara di Semenanjung Arab yang terlibat peperangan dengan kelompok ISIS merebut kembali sebagian wilayah yang sempat dikuasai militan Negara Islam, seperti keberhasilan militer Libya merebut kembali ibu kota Sirte (Alkhshali, 2016) dan kembali jatuhnya Fallujah ke tangan pemerintah Irak sejak wilayah tersebut dikuasai ISIS pada tahun 2014 (Al-Jazeera, 2016). Peta yang dirilis Pentagon pada pertengahan tahun 2015 menunjukkan pasukan koalisi Amerika Serikat telah berhasil merebut kembali 25\%-30\% wilayah Iraq dari 
ISIS (Mackay, 2016). Ini menunjukkan bahwa dalam kurun waktu dua tahun perlawanan, negara-negara Arab bersama pasukan koalisi mereka, membuat kekuatan ISIS di kawasan menurun dan posisinya semakin terdesak.

Dalam perkembangan terakhir, operasi militer lanjutan pemerintah Irak untuk membebaskan kota Mosul yang diklaim sebagai basis pertahanan terakhir militan ISIS di Irak dinilai segera mengakhiri kekuatan ISIS di negara tersebut. Sementara di Suriah, pasukan militer rezim Bashar Al-Assad yang didukung militer Rusia juga telah mengepung kota strategis Palmyra. Keberhasilan merebut kota tersebut akan menjadi kemenangan penting bagi Pemerintah Suriah untuk kembali menguasai wilayah yang terletak di antara Suriah bagian tengah dan Irak (Kompas, 2016). Terbunuhnya beberapa pimpinan penting ISIS, seperti Abu Muhammad al-Adnani yang dikenal sebagai arsitek serangan teror sekaligus aktor penting di balik propaganda dan jaringan teroris yang tersebar di berbagai negara, membuat kelompok tersebut juga kehilangan kader potensial yang berpengaruh cukup signifikan bagi keberhasilan strategi yang mereka jalankan (Huffington Post, 2016).

Selanjutnya, berdasarkan data yang diungkap oleh defence analysts IHS, sejak meningkatnya serangan yang dilakukan oleh kubu pemerintah Irak dan Suriah dalam merebut kembali wilayah mereka melalui operasi militer darat maupun udara pada awal 2015, kelompok jihadis ISIS telah kehilangan sekitar 28\% wilayah kekuasaannya. Terhitung sepanjang sembilan bulan di tahun 2016, mereka juga telah kehilangan wilayah kekuasaan dari 30,115 mil persegi menjadi 25,290 mil persegi atau setara luas wilayah Sri Lanka (Mortimer, 2016). Meski hal tersebut belum menggambarkan ancaman ISIS di kawasan tersebut akan segera berakhir, namun dengan semakin berkurangnya kekuatan mereka secara drastis dan hilangnya kontrol atas beberapa wilayah strategis, dapat menjadi indikasi kejatuhan pasukan Negara Islam Irak dan Suriah di Timur Tengah. Terlebih lagi, selain telah kehilangan wilayah kekuasaanya di Mosul, keberhasilan pasukan SDF (Suriah Democatic Forces) merebut kembali 90\% wilayah Raqqa yang selama ini menjadi jantung kekuatan jihadis ISIS di Suriah pada penghujung tahun 2017, juga telah menjadi simbol berakhirnya kekhalifahan ISIS di kawasan tersebut (Davison \& Said, 2017).

Kekalahan yang terus dialami oleh ISIS di Irak dan Suriah memang telah membuka peluang bagi berakhirnya kekerasan dan terciptanya keamanan di kawasan tersebut. Akan tetapi, propaganda ISIS yang telah menyebar luas dan melahirkan jaringan jihadis di berbagai kawasan di luar Timur Tengah, berpotensi dimanfaatkan untuk memperluas agenda jihad dan menegakkan Negara Islam di wilayah yang baru. Beberapa analis menilai, kekalahan di dua kota besar di Irak dan Suriah belum dapat dikatakan sebagai akhir perjuangan kelompok ISIS. Ini disebabkan mereka telah menyebarkan ideologinya ke seluruh dunia dan berhasil memotivasi para jihadis untuk melakukan serangan di berbagai penjuru dunia. Menurut Hassan, seorang analis senior di Tahrir Institute for Middle East Policy di Wahington, ISIS telah menjadi organisasi internasional, oleh karena itu, kemampuan untuk membangun kembali kekuatan dan kepemimpinannya tetap ada (Hubbard \& Schmitt, 2017).

Dalam konteks potensi kebangkitan kembali kelompok Negara Islam, khususnya di luar kawasan Timur Tengah, salah satu kawasan yang berpotensi besar menjadi target mereka adalah Asia Tenggara. Selain karena kawasan ini telah lama dikenal sebagai basis bagi gerakan teroris maupun kelompok militan Islam radikal seperti Jamaah Islamiyah (JI) dan alQaeda, dalam perkembangan terakhir, ISIS juga telah mendeklarasikan jaringan sayap lokal dari Asia Tenggara yang dikenal dengan 'Katibah Nusantara' (Pandey, 2016). Rencananya, jaringan tersebut tidak hanya akan dimanfaatkan untuk keperluan perekrutan dan memfasilitasi pengiriman simpatisan ke Irak dan Suriah, melainkan juga dipersiapkan untuk mengorganisir serangan di beberapa negara di Asia Tenggara, seperti Indonesia, Malaysia, Singapura, 
dan Filipina. Rangkaian serangan bom di beberapa negara di kawasan dalam kurun waktu empat tahun terakhir hingga meletusnya pertempuran di kota Marawi, wilayah bagian selatan Filipina pada awal tahun 2017 yang melibatkan jihadis maupun kelompok yang mengklaim berafiliasi dengan ISIS juga membuktikan bahwa kawasan Asia Tenggara telah dihadapkan pada ancaman kelompok terorisme Negara Islam Irak dan Suriah (ISIS).

Satu hal yang perlu dicatat, Asia Tenggara masih menyisakan banyak permasalahan, yang berkaitan dengan isu keamanan, baik yang bersifat ancaman keamanan dari negara lain seperti ancaman invasi militer akibat sengketa wilayah perbatasan antar negara di ASEAN maupun dengan Cina di wilayah Laut Cina Selatan dan ancaman pengembangan senjata nuklir Korea Utara, hingga ancaman keamanan yang muncul akibat gesekan antar entitas dalam ruang-ruang sosial seperti konflik etnis di Myanmar, ancaman kelompok-kelompok radikal di Indonesia, Malaysia dan Filipina menjadikan kawasan ini juga masih rentan dan sensitif terhadap isu-isu yang menyeret pada konflik, terutama yang menyangkut identitas dan keyakinan, mengingat kawasan ini memiliki kekayaan etnis, suku, dan aliran kepercayaan yang sangat beragam. Terlebih lagi, di era globalisasi, di mana kemudahan dalam mengakses informasi tanpa batas melalui tersedianya teknologi yang canggih dan murah, telah berperan besar dalam menyebarkan universalitas keyakinan bagi individu, kelompok, maupun organisasi yang merasa memiliki kesamaan dalam memandang suatu hal, misalnya ideologi politik, agama, maupun budaya yang dapat dijadikan motivasi untuk melakukan berbagai tindakan, termasuk terorisme. Trend semacam inilah yang menjadi salah satu faktor utama meluasnya ideologi dan keyakinan untuk membenarkan tindakan kekerasan maupun terorisme (Winarno, 2011:174).

Tulisan ini akan membahas meningkatnya potensi ancaman ISIS di Asia Tenggara sebagai bagian dari fenomena terorisme global dan penguatan kerja sama negara-negara di kawasan sebagai upaya sekuritisasi dalam menghadapi ancaman tersebut. Peningkatan kerja sama keamanan kawasan dan tindak lanjut program sekuritisasi dari ancaman teror yang belum berjalan baik menjadi langkah yang ditempuh negara-negara di kawasan untuk menghadapi potensi meluasnya ancaman ISIS di Asia Tenggara. Upaya menangkal ancaman ISIS secara bersama tersebut mutlak dilakukan mengingat adanya potensi terbukanya wilayah di Asia Tenggara seperti Selat Sulu sebagai area strategis yang dapat dimanfaatkan oleh para jihadis ISIS di Asia Tenggara untuk memobilisasi kekuatan mereka.

\section{PEMBAHASAN}

\section{ISIS DAN TERORISME GLOBAL}

Segala bentuk ancaman yang dimunculkan oleh aktivitas terorisme khususnya di era globalisasi, baik yang secara langsung menimpa para korban berupa kehilangan nyawa mereka akibat serangan teror atau secara tidak langsung berupa bayang-bayang rasa tidak aman ketika berada di tempat umum, tempat peribadatan, maupun dampak psikis akibat propaganda kelompok terorisme yang dimuat di media, cukup membuktikan bahwa ancaman terorisme telah menjadi bagian dari kehidupan seharihari setiap individu.

Meluasnya eksistensi terorisme secara global, baik keterlibatan aktor, perluasan jaringan, dan aksiaksi yang dilakukan, salah satunya dapat dipahami sebagai implikasi yang dibawa oleh arus globalisasi. Menurut Winarno (2014), setidaknya terdapat tiga faktor utama yang menyebabkan meluasnya terosisme secara global. Pertama, adanya kemajuan di bidang transportasi terutama transportasi udara. Perpindahan arus barang, modal, manusia dan semakin luasnya jangkauan transportasi udara juga turut memberi peluang yang besar bagi meluasnya terorisme. Kedua, adanya kesamaan ideologi dan kepentingan di seluruh dunia. Satu hal yang perlu dipahami, globalisasi tidak hanya mengenai perpindahan barang dan manusia, tapi juga meliputi gagasan atau ide. Kemajuan teknologi informasi seperti lahirnya internet dan 
portal-portal media komunikasi berbasis online telah menjadi faktor kunci dan alat yang efektif untuk menyebarkan informasi secara cepat dan luas. Tentu saja, perkembangan tersebut juga memberi ruang yang lebih besar bagi kelompok terorisme untuk menyebarkan ideologi dan propaganda ke seluruh dunia maupun membangun koneksi dengan jaringan teroris di negara lain. Oleh karena itu, seiring dengan semakin terbukanya akses bagi tersebarnya informasi dan luasnya jangkauan distribusi barang melalui tersedianya teknologi yang semakin canggih, semakin menjelaskan mengapa karakter terorisme di era globalisasi hari ini lebih bersifat trans-nasional dan trans-regional (Seib \& Janbek, 2011:58). Semakin meluasnya eksistensi terorisme secara global juga dimungkinkan dengan adanya perangkat-perangkat yang mampu mereka gunakan untuk merahasiakan komunikasi, aliran dana, dan perpindahan anggota mereka dengan cepat tanpa mudah terdeteksi (Djelantik, 2010:132).

Berkaitan dengan perkembangan teknologi informasi, dan hal ini sekaligus menjadi faktor ketiga yang menyebabkan meluasnya terorisme selain yang telah dijelaskan di atas, yaitu coverage media informasi yang berperan penting di dalam menyebarkan informasi mengenai terorisme melalui pemberitaan aksi-aksi teror di berbagai belahan dunia. Dalam hal ini, masih menurut Winarno (2014), peran media informasi publik seperti televisi memainkan peran penting dalam memperluas informasi mengenai terorisme. Liputan tentang terorisme yang disajikan dalam bentuk visual dan suara, tayangan yang disiarkan secara berulang, hingga siaran yang bersifat live semakin memperluas jangkauan khalayak umum untuk mendapatkan informasi mengenai terorisme.

Tidak dapat dipungkiri, globalisasi pada dasarnya telah mendorong perubahan besar bagi peradaban manusia. Gagasan untuk menciptakan sebuah desa global yang didasari semakin mudahnya transaksi trans-regional juga telah meningkatkan keyakinan bahwa homogenitas masyarakat global baik dalam hal politik, ekonomi, dan sosial telah berakhir.
Semakin mudahnya perpindahan modal, tenaga kerja, gagasan, dan teknologi melintasi batas-batas wilayah negara juga mendorong semakin longgarnya pergeseran tatanan keamanan. Terorisme global adalah salah satu fenomena yang lahir dan kalau boleh dikatakan berkembang melalui fasilitas-fasilitas yang disediakan oleh globalisasi. Hal tersebut oleh Muqtedar Khan (2001) disebut sebagai salah satu bentuk ironi globalisasi, karena di satu sisi globalisasi telah menjadi pendorong suksesnya perkembangan terorisme global yang menjadi ancaman dan musuh negara di dunia, di sisi lain terorisme global juga menjadi tantangan terbesar bagi globalisasi itu sendiri.

Peristiwa 11 September 2001 memang menjadi peristiwa penting yang menandai sekaligus menegaskan bahwa terorisme merupakan ancaman serius bagi masyarakat dunia. Namun, di era globalisasi dan teknologi informasi sekarang ini, ancaman yang muncul dapat lebih dari apa yang dibayangkan. Aksi-aksi teror tidak hanya akan dapat dikoordinasikan dan dijalankan secara efektif dengan memanfaatkan teknologi komunikasi yang canggih sebagaimana aksi bom bunuh diri di London pada tahun 2005. Lebih dari itu, di masa depan ancaman terorisme diprediksi tidak hanya sebatas akan menggunakan senjata-senjata konvensional untuk menebar ancaman, karena dengan kemampuan penguasaan teknologi digital yang mumpuni atau yang diistilahkan dengan kemampuan 'cyber-terror', mereka juga dapat melumpuhkan aktivitas pada sektor-sektor vital yang menunjang kehidupan seperti perekonomian, bahkan, dapat menyebabkan bencana besar jika kemampuan penguasaan teknologi yang mereka miliki digunakan untuk mengambil alih sumber daya strategis seperti tenaga nuklir.

ISIS sebagai kelompok teroris yang lahir dan berkembang seiring dengan meningkatnya peran teknologi informasi, kalau boleh dikatakan, cukup merepresentasikan bagaimana karakteristik terorisme di era globalisasi dan kemajuan teknologi informasi. Merujuk penjelasan Charles Lister dalam tulisan Samuel Makinda, Terrorism in International Society: An 
Eclectic Perspective (2016), keberhasilan ISIS dalam mendistribusikan pengaruh dan kekuatannya sejak berdiri pada tahun 2014, selain karena kelompok tersebut memiliki persenjataan berat dan canggih dan beroperasi sebagai organisasi yang terlatih, faktor lain yang tidak kalah penting adalah penguasaan yang baik terhadap media sosial. Meski beberapa analis menyebutnya sebagai organisasi abad pertengahan, kenyataannya mereka sangat fasih dalam menggunakan teknologi modern dan media sosial (Makinda, 2016).

Dalam konteks pembahasan mengenai ancaman terorisme di Asia Tenggara, seperti yang telah disinggung sebelumnya, kawasan ini telah sejak lama diketahui sebagai basis kelompok militan Islam radikal sekaligus jaringan teroris global. Jika merujuk pada penjelasan dalam U.S Congressional Research Service tahun 2009 mengenai gerakan kelompok Islam radikal di Asia Tenggara, pada awal perkembangannya, pola pergerakan kelompokkelompok Islam radikal di kawasan tersebut hanya terfokus pada isu domestik di masing-masing negara dan hubungan jaringan yang terbentuk antar kelompok militan di kawasan cenderung lemah. Namun, setelah periode 1990-an, di mana trend dan penetrasi globalisasi telah membawa banyak perubahan dalam konstelasi global, kelompokkelompok radikal Islam di kawasan tersebut mulai menemukan momentum untuk memperluas pergerakan hingga keluar kawasan. Isu-isu yang menjadi fokus mereka juga menjadi lebih luas, seperti kecaman keras terhadap pendudukan Israel di Gaza, kekecewaan terhadap kebijakan-kebijakan pemerintahan sekuler, meningkatnya sentimen antiBarat yang dapat dikaitkan dengan besarnya pengaruh Amerika Serikat di kawasan, serta meningkatnya kesadaran untuk memperkuat jaringan di kawasan dengan mendirikan "Pan-Islam" di Asia Tenggara.

Oleh karena itu, tidak mengherankan jika kekhawatiran terhadap ancaman Negara Islam Irak dan Suriah (ISIS) yang mulai meluas sejak pertengahan tahun 2014 lalu, juga berkembang dan menjadi salah satu isu penting bagi dinamika keamanan di Asia Tenggara hari ini. Kekhawatiran tersebut muncul dari beberapa fakta yang menunjukkan bahwa kawasan ini telah menjadi bagian dari jaringan Negara Islam dan berkontribusi cukup signifikan dalam mendukung kekuatan pasukan militan Negara Islam di Irak dan Suriah. Ini dibuktikan dengan bergabungnya sekitar 1.000 jihadis dari seluruh sub-kawasan Asia, termasuk Asia Tenggara dalam peperangan di Irak dan Suriah (Hashim, 2015:1). Berikutnya, fakta lain yang diprediksi memperbesar potensi hadirnya ISIS di Asia Tenggara adalah dukungan simpatisan jihadis baik dari kalangan individu (lone wolf) ${ }^{1}$ maupun jaringan sayap lokal di kawasan yang telah berafiliasi dan mendukung perjuangan berdirinya Negara Islam, kembalinya beberapa pejuang ISIS dari Irak dan Suriah ke masing-masing negara asal mereka akibat kekalahan yang diderita, dan meningkatnya sentimen antar kelompok yang berlatar belakang etnis dan keyakinan agama di beberapa negara di Asia Tenggara dalam beberapa waktu terakhir, menjadi beberapa faktor yang dapat dimanfaatkan oleh kelompok teroris sebagai bahan propaganda untuk membuka konflik. Tidak dapat dipungkiri, sebagai kawasan yang dihuni oleh $15 \%$ penduduk muslim dunia dengan berbagai macam aliran dan sekte, termasuk aktivis muslim fundamentalis dan ekstrimis, Asia Tenggara menjadi kawasan yang sangat rentan terhadap propaganda dan pengaruh dari kelompok militan Islam radikal (Chalk, 2015:10).

\section{ANCAMAN ISIS DI ASIA TENGGARA}

Indikasi hadirnya ancaman ISIS di Asia Tenggara diperkuat dengan diangkatnya pimpinan Abu Sayyaf, Isnilon Hapilon, sebagai Amir ISIS di Asia Tenggara oleh pemimpin tertinggi ISIS, Abu Bakr al-Baghdadi pada tahun 2016 di Filipina, yang juga rencananya akan mendirikan salah satu provinsi di bawah kekuasaan Kekhalifahan Negara Islam. "Wilayat" atau provinsi Negara Islam yang akan didirikan di Filipina bagian selatan tersebut diproyeksi 
sebagai representasi kekhalifahan Islam di Asia Tenggara. "Wilayat" tersebut akan dijadikan sebagai basis dan transit bagi militan Negara Islam Asia Tenggara sekembalinya dari Timur Tengah untuk melanjutkan perjuangan mendirikan Negara Islam di kawasan atau di negara mereka berasal. Rencana pendirian "wilayat" Negara Islam tersebut sejalan dengan meningkatnya aktivitas militan ISIS asal Asia Tenggara dalam menjalankan propaganda jihad di Timur Tengah, yang sebelumnya juga telah mendeklarasikan berdirinya sayap lokal ISIS Asia Tenggara di Irak dan Suriah yang dikenal dengan "Katibah Nusantara" (Liow, 2015).

Sejumlah aksi yang terjadi dalam beberapa tahun terakhir, seperti serangan bom di Jakarta pada awal tahun 2014, ancaman aksi bom bunuh diri di Kuala Lumpur di penghujung tahun 2015, maupun bom mobil yang meledak di Thailand pada pertengahan tahun 2017, yang mana serangkaian peristiwa tersebut diklaim merupakan aksi yang didalangi oleh kelompok-kelompok militan Islam yang terindikasi berafiliasi dengan ISIS menjadi bukti serius ancaman kelompok teroris di bawah bendera Negara Islam di kawasan. Untuk memberi gambaran lebih jelas mengenai serangkaian serangan teror di kawasan sepanjang dua tahun terakhir dapat dilihat pada Gambar 1.

Gambar 1. Serangan oleh kelompok militan Islam di kawasan Asia Tenggara sepanjang tahun 2016-2017

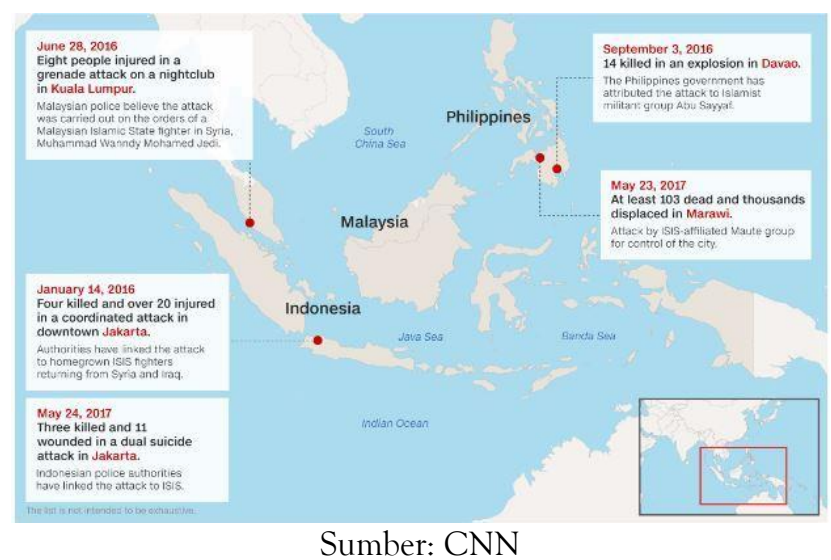

Sumber: CNN
Selain itu, keberangkatan beberapa warga Indonesia maupun Malaysia untuk bergabung menjadi pasukan Abu-Bakr Al-Baghdadi juga terbilang signifikan. Berdasarkan data yang dipublikasikan oleh CNN pada awal tahun 2016, terdapat sekitar 700 pejuang Negara Islam asal Indonesia yang berangkat menuju Suriah dan sekitar 200 asal Malaysia (Edwards, 2016). Ini membuktikan bahwa propaganda dan upaya radikalisasi kelompok Negara Islam di Asia Tenggara mendapat simpati yang besar, dan sekali lagi, ini menjadi fakta yang harus dihadapi. Namun, puncak kekhawatiran dari itu semua adalah ketika kembalinya para pejuang Negara Islam dari Timur Tengah yang berbekal pengalaman terlibat dalam peperangan dan strategi dalam melakukan penyerangan yang pernah mereka dapatkan di Irak dan Suriah serta dukungan penuh dari kelompok lokal yang berafiliasi dengan ISIS dapat mereka gunakan untuk menyelenggarakan serangan di kawasan, terutama di negara mereka berasal (Hashim, 2015:9). Tidak hanya itu, Rohan Gunaratna, kepala International Centre for Political Violence and Terrorism Research, menyatakan bahwa para jihadis yang kembali ke Asia Tenggara juga dibekali ratusan ribu dolar untuk membiayai dan mempersiapkan rancangan penyerangan (Osborne, 2016).

Lebih lanjut, dalam konteks meningkatnya pergerakan ISIS di kawasan, faktor lain yang tidak kalah penting adalah keberhasilannya dalam memperoleh dukungan dari kelompok-kelompok militan lokal di kawasan. Berdasarkan laporan terakhir dari Instititute for Policy Analysis and Conflict (2016), setidaknya terdapat empat kelompok militan lokal di Mindanao yang juga terhubung dengan kelompok di Indonesia dan Malaysia yang secara aktif mendukung proyek ISIS di kawasan. Beberapa kelompok tersebut di antaranya adalah kelompok Abu Sayyaf (ASG) yang berbasis di Basilan, Ansarul Khilafa Philippines (AKP), kelompok Maute di Lanao del sur, dan Bangsamoro Islamic Freedom Fighters (BIFF). Keseluruhan dari kelompok tersebut memiliki pejuang militan yang berpengalaman melakukan 
pertempuran, instruktur beserta fasilitas pelatihan, dan sumber pendanaan dari kelompok Indonesia dan Malaysia. Para pejuang-pejuang tersebut juga dibekali persenjataan, alat komunikasi canggih, serta pengetahuan tambahan mengenai strategi pertempuran oleh para pejuang dari luar kawasan (Foreign Fighters) yang dikirim untuk membantu Abu Sayyaf dalam menyelenggarakan serangkaian pertempuran. Oleh karena itu, menurut direktur IPAC, Sidney Jones, hadirnya ISIS di kawasan Asia Tenggara membuka ruang bagi kelompok-kelompok lokal untuk semakin memperkuat kerja sama antarkelompok selain membuka peluang bagi ISIS untuk memulai membangun kekuatan baru di wilayah lain seiring kekalahan besar di Timur Tengah (IPAC, 2016).

Dengan demikian, semakin jelas bahwa ancaman Negara Islam di Asia Tenggara semakin hari semakin meluas dan menyebar dengan cepat, khususnya di negara-negara dengan penduduk muslim seperti Indonesia, Malaysia, Singapura, dan Filipina, yang sebagian wilayahnya berpenduduk muslim. Hal itu dipertegas oleh pernyataan Menteri Pertahanan Singapura, Ng Eng Hen, yang menyatakan bahwa ISIS telah berhasil merekrut lebih banyak orang di kawasan Asia Tenggara, khususnya dari Indonesia, Malaysia, dan Singapura. Selain itu, dukungan dari jaringan teroris lokal seperti Jamaah Islamiyah dan kelompok separatis Maute yang telah berafiliasi dengan Abu Sayyaf, turut mempercepat perluasan ancaman Negara Islam di Asia Tenggara (Maulana, 2015).

Senada dengan apa yang disampaikan Menteri Pertahanan Singapura, beberapa tahun yang lalu, dalam acara Shangri-La Dialogue yang digelar di Singapura pada pertengahan tahun 2015, Perdana Menteri Singapura, Lee Hsien Loong juga menyatakan bahwa Asia Tenggara merupakan kawasan yang menjadi pusat perekrutan simpatisan ISIS. Ia juga memperingatkan, di beberapa wilayah yang tidak mendapatkan perhatian dari pemerintah negaranegara di kawasan, akan sangat mudah dimanfaatkan oleh kelompok teroris untuk dijadikan sebagai wilayah kekuasaan dan menyusun serangan serta perekrutan anggota baru. Kekhawatiran pimpinan negara-negara di Asia Tenggara terhadap cepatnya perluasan ancaman ISIS di kawasan sesuai dengan fakta di mana cukup banyaknya simpatisan dari kawasan ini yang merasa terpanggil untuk bergabung setelah melihat beberapa tayangan propaganda yang disebar ISIS melalui media sosial. Bahkan, dalam kasus penangkapan yang terjadi di Singapura, simpatisan yang diduga terlibat kelompok teroris Negara Islam dan berencana melakukan serangan di Singapura adalah dua orang pelajar, dengan kisaran usia 17 dan 19 tahun (Rogin, 2016). Hal ini menunjukkan bahwa propaganda yang dilakukan ISIS di Asia Tenggara melalui media khususnya media digital dalam bentuk teks, gambar, maupun tayangan video yang disebar secara masif, telah berhasil menarik perhatian para simpatisannya di kawasan ini untuk segera bergabung di bawah bendera hitam Negara Islam Irak dan Suriah.

\section{PERTEMPURAN DI MARAWI}

Peringatan yang pernah disampaikan oleh PM Singapura Lee Hsien Loong di tahun 2015 nampaknya tidak perlu waktu lama untuk dibuktikan. Di awal tahun 2017, pertempuran antara militer Filipina (Armed Forces of The Philippines) dengan militan Negara Islam Irak dan Suriah di kota Marawi, salah satu daerah di bagian selatan pulau Mindanao sekaligus menjadi satu-satunya wilayah di Filipina yang memiliki populasi penduduk muslim yang cukup signifikan, menjadi bukti bahwa ancaman ISIS di Asia Tenggara menjadi kenyataan yang tidak dapat dipungkiri. Sebagai wilayah yang tidak begitu mendapatkan perhatian, khususnya dalam segi keamanan dari otoritas pemerintahan Filipina maupun negara-negara di Asia Tenggara karena beberapa tahun terakhir fokus peningkatan pengamanan seperti yang dilakukan oleh Indonesia dan Malaysia terhadap aktivitas jihadis di kawasan juga lebih ditujukan kepada kelompok lokal Jamaah Islamiyah, nampaknya dimanfaatkan oleh kelompok 
militan ISIS untuk menguasai kota kecil tersebut dan menjadikannya sebagai basis kekuatan di Asia Tenggara. Selain itu, anggapan para analis bahwa para jihadis di kawasan merasa kecewa terhadap pengangkatan Hapilon sebagai "Emir wilayat" di Asia Tenggara oleh Abu Bakar Al-Baghdadi, juga, anggapan bahwa sejak Hapilon lebih memfokuskan aktivitasnya di luar wilayah kekuasaannya di Basilan, menjadikan wilayah yang terletak di bagian selatan Filipina tersebut tidak begitu diperhatikan oleh otoritas keamanan di kawasan maupun analis, oleh karena itu, wilayah tersebut dapat dengan mudah jatuh ke tangan ISIS (MacNeil, 2017).

Meskipun pada akhirnya pasukan militer Filipina berhasil mengembalikan keamanan di Marawi, pertempuran tersebut dapat menjadi alasan kuat untuk menyatakan bahwa ISIS telah menemukan pintu masuk untuk mengawali ekspansi di Asia Tenggara. Mengacu pernyataan dari International Center for Political Violence and Terrorism Research yang berpusat di Singapura, langkah ISIS untuk memulai mengekspansi kawasan dimulai dengan menjadikan Filipina sebagai pusat kekuatan mereka, di mana terdapat lebih 60 kelompok yang telah menyatakan dukungan kepada ISIS (Maresca, 2017). Lebih lanjut, mengutip pernyataan Jones, pertempuran di Marawi hanyalah salah satu alternatif kelompok Negara Islam untuk mengawali eksistensi mereka di kawasan, karena hal serupa juga berpotensi terjadi di wilayah lain di kawasan seperti di sepanjang perbatasan Banglades dan Myanmar, di mana terdapat ribuan muslim Rohingya yang sedang berupaya membebaskan diri dari konflik di wilayah mereka. Ia memprediksi, dalam beberapa tahun ke depan para jihadis juga akan tertarik untuk bergabung bersama pemberontak Rohingya di Myanmar (Westerman, 2017).

Pertempuran yang berlangsung selama lima bulan antara pasukan militer Filipina dan jihadis ISIS di kota Marawi tidak dapat dipandang secara sederhana sebagai kontak senjata yang hanya melibatkan kelompok militan lokal, melainkan perlu dipandang sebagai bentuk vis-à-vis dengan kelompok teroris terbesar saat ini karena dalam pertempuran tersebut telah melibatkan jihadis dari berbagai negara, baik dari negara tetangga di kawasan seperti Indonesia dan Malaysia, maupun dari negara di luar kawasan. Pertempuran tersebut juga dapat menjadi proyeksi ancaman utama bagi stabilitas keamanan di kawasan pada waktu mendatang, mengingat setelah Perang Dunia II, pertempuran tersebut menjadi salah satu pertempuran paling mematikan di Asia Tenggara (Santos \& Welle, 2017). Lebih khusus, dalam konteks serangan teror, krisis di Marawi menjadi serangan teroris paling signifikan setelah peristiwa bom Bali II yang menewaskan sekitar 202 orang dengan alasan peristiwa tersebut menjadi permulaan yang sukses bagi jihadis ISIS dalam mengawali kehadirannya di Asia Tenggara (Fealy, 2017). Oleh karena itu, negara-negara di kawasan perlu segera menyadari bahwa hadirnya ISIS di Asia Tenggara menjadi isu keamanan yang perlu mendapat perhatian serius, terutama setelah mereka mengalami kekalahan besar di Timur Tengah.

\section{PENGUATAN KERJA SAMA KEAMANAN KAWASAN SEBAGAI UPAYA SEKURITISASI DALAM MENGHADAPI ANCAMAN ISIS DI ASIA TENGGARA}

Setelah pasukan militer Filipina berhasil mengakhiri kontak senjata dengan jihadis ISIS, bahkan mengklaim berhasil membunuh dua tokoh penting dari pihak mereka, Isnilon Hapilon dan Omar Maute, bukan berarti permasalahan di wilayah tersebut selesai. Sebaliknya, peristiwa tersebut justru mempertegas peringatan bagi negara-negara di kawasan bahwa ancaman ISIS bukan hanya masalah yang dihadapi oleh Irak dan Suriah atau negara-negara di Timur Tengah pada umumnya, tetapi telah menjadi masalah global, tidak terkecuali bagi Asia Tenggara. Oleh karena itu, dengan berkibarnya bendera hitam Negara Islam Irak dan Suriah di wilayah Filipina bagian selatan bersamaan dengan aksi bom bunuh diri di Jakarta yang juga dilakukan oleh simpatisan ISIS pada awal 2017 lalu, mengindikasikan 
adanya tantangan yang lebih besar bagi negara-negara di Asia Tenggara dalam menghadapi ancaman terorisme global.

Paska serangkaian peristiwa tersebut, kehadiran ISIS menjadi ancaman yang esensial bagi negaranegara di Asia Tenggara, sehingga respon cepat seluruh negara di kawasan untuk melakukan sekuritisasi menjadi hal yang mutlak. Sekuritisasi dapat dipahami sebagai langkah yang ditempuh oleh suatu aktor (securitizing actors) melalui penggunaan cara-cara yang tidak biasa, atau mengambil tindakan politik secara khusus untuk menghadapi suatu ancaman (Buzan, Weaver, \& Wilde, 1998: 25). Dalam konteks tulisan ini, dan sekaligus untuk memahami peningkatan kerja sama keamanan di Asia Tenggara sebagai bentuk sekuritisasi yang dilakukan dapat ditinjau dari komponen sekuritisasi berikut; negaranegara di Asia Tenggara merupakan aktor yang melakukan upaya sekuritisasi dari segala bentuk ancaman (existence threat) yang dilakukan oleh ISIS (audience) sebagai sumber ancaman yang muncul, dengan tujuan untuk menciptakan dan melindungi seluruh masyarakat di kawasan (referent object) dari bahaya ISIS (Buzan, Weaver, \& Wilde, 1998: 25). Upaya sekuritisasi mulai diperlihatkan oleh negaranegara di kawasan dalam forum keamanan tertinggi ASEAN ke-11, atau yang dikenal dengan ADDM (ASEAN Defense Minister Meeting) yang diselenggarakan di akhir tahun 2017 di Filipina, di mana ancaman terorisme ISIS menjadi sorotan utama para menteri pertahanan negara-negara di kawasan dan mendorong mereka untuk mempererat kerja sama dalam mengatasi ancaman tersebut (Bacungan \& Jiao, 2017). Dalam pertemuan tersebut, beberapa negara mitra seperti China, Rusia, India, Jepang, Korea Selatan, Selandia Baru dan Amerika Serikat juga terlibat melalui forum ADDM-Plus. Pada pertemuan selanjutnya, juga dalam forum yang sama yang diselenggarakan di awal tahun 2018 di Singapura, para menteri pertahanan di ASEAN sepakat bahwa meningkatnya eskalasi dan kompleksitas ancaman terorisme di kawasan mendorong mereka untuk segera melakukan kerja sama praktis untuk meningkatkan ketahanan ASEAN dari ancaman terorisme, mempercepat respon ancaman yang berlangsung dan pemulihan paska serangan terjadi (Siong, 2018).

Sebelumnya, dalam ASEAN Summit ke-31 di Manila, seluruh negara-negara di Asia Tenggara dan mitra dialog seperti Amerika Serikat, Australia dan Kanada juga menegaskan komitmen untuk bekerja bersama dalam mengantisipasi kemungkinan terulangnya krisis di Marawi. Hal itu penting untuk dilakukan mengingat paska krisis di Marawi, ancaman ISIS belum dapat dikatakan berakhir dan potensi hadirnya ancaman teroris di kawasan dapat meletus di mana saja dikarenakan simpatisan ISIS tidak hanya datang dari wilayah Filipina, tetapi telah menyebar ke sebagian besar negara di kawasan seperti Malaysia, Indonesia, dan Singapura (Fonbuena, 2017). Langkah atraktif lain yang segera dilakukan dalam rangka merespon perkembangan situasi keamanan yang terjadi di kawasan adalah diselenggarakannya pertemuan sub-regional enam negara di Manado, Sulawesi Utara pada akhir juli 2017. Pertemuan yang melibatkan Indonesia, Malaysia, Brunei, Filipina, Selandia Baru dan Australia tersebut merumuskan beberapa kesepakatan dan rencana lanjutan dalam rangka menghadapi ancaman terorisme dan Foreign Terrorist Fighters (FTF) di Asia Tenggara. Di antara kesepakatan tersebut adalah peningkatan program deradikalisasi serta penyusunan narasi untuk melawan propaganda terorisme yang menjadi akar dari lahirnya radikalisme dan ekstrimisme, rencana pembentukan forum FTF yang bertujuan sebagai wadah berbagi informasi dan kerja sama antar penegak hukum dan intelijen, peningkatan kerja sama badan integrasi sebagai wujud pengawasan terpadu, dan kerja sama dengan perusahaan-perusahaan layanan media sosial, mengingat di era teknologi informasi saat ini, pengawasan terhadap komunikasi berbasis internet perlu mendapat perhatian lebih. Di samping itu, pertemuan tersebut juga menghasilkan kesepakatan lanjutan berupa perluasan kerja sama penanggulangan 
terorisme, khususnya Cross Border Terrorism di sub kawasan Asia (VOA Indonesia, 2017).

Upaya untuk memutus aliran dana terorisme di kawasan juga segera dilakukan dengan membangun aliansi dengan Australia, di mana Badan Intelijen Keuangan Australia (AUSTRAC) beserta Dewan AntiPencurian Uang Filipina dipercaya mengawasi transaksi keuangan mencurigakan dari sumber-sumber keuangan internasional yang masuk ke wilayah Asia Tenggara (Suastha, 2017). Khusus dengan Australia, ASEAN telah mengambil langkah yang lebih konkrit. Tercapainya kesepakatan kerja sama pemberantasan terorisme dan ekstrimisme dalam pertemuan yang bertajuk ASEAN-Australia Special Summit 2018 di Sidney, menjadi sebuah pencapaian penting bagi ASEAN dan Australia dalam menghadapi ancaman terorisme di kawasan. Melalui MoU yang disepakati, baik ASEAN maupun Australia berkomitmen untuk merumuskan dan mengimplementasikan undangundang anti terorisme secara konsisten dengan menerapkan standar internasional. Selain itu, kesepakatan tersebut juga menyertakan perlunya pembahasan isu-isu yang lebih komprehensif terkait penanganan terorisme, seperti pembahasan mengenai diperlukannya bukti elektronik dalam proses investigasi maupun proses peradilan terorisme, program pertukaran intelijen keuangan secara multilateral, hingga dialog tingkat regional yang secara khusus mengakomodasi para penegak hukum di Asia Tenggara dan Australia (Yahya, 2018). Langkah tersebut perlu dilakukan mengingat aktivitas terorisme di era modern telah menggunakan metode nonkonvensional dalam melakukan serangan maupun pendanaan. Hal ini ditegaskan oleh pernyataan Perdana Menteri Australia, Malcolm Turnbul, yang menyatakan bahwa mulai digunakannya uang digital, store value cards, atau paltform crowdfunding menjadikan aktivitas pendanaan mereka sulit untuk dideteksi.

Sedang tingkat regional ASEAN, Indonesia, Malaysia, dan Filipina menjadi tiga negara yang paling serius mendorong agar kerja sama pemberantasan terorisme di kawasan semakin ditingkatkan terutama dalam hal pengawasan aliran pendanaan, komunikasi, dan persenjataan. Bahkan, menanggapi kritikan para pemerhati kawasan yang mengatakan bahwa selama ini negara-negara di kawasan tidak menunjukkan kerja sama yang baik dalam mengantisipasi ancaman keamanan, terutama dari terorisme, ketiga negara tersebut segera menyusun ulang program operasi gabungan untuk mengawasi pergerakan para militan khususnya setelah mereka kalah dalam pertempuran di Marawi. Para Menteri Luar Negeri dan otoritas pertahanan ketiga negara tersebut sepakat untuk mengambil langkah strategis dan menyusun ulang program sekuritisasi yang selama ini belum diimplementasikan dengan baik, khususnya bagi Filipina yang dipandang paling lemah dalam hal tersebut (Morales \& Mogato, 2017). Lebih spesifik, upaya pengawasan terhadap pergerakan dan potensi perluasan kekuatan ISIS di kawasan dilakukan dengan operasi pengamanan gabungan di wilayah perbatasan ketiga negara tersebut, khususnya di wilayah perairan. Patroli gabungan tersebut juga dikenal dengan istilah 'The Trilateral Maritime Patrol Indomalphi,' di mana istilah 'Indomalphi' diambil dari gabungan ketiga nama negara yang menginisiasi dan mengimplementasikan, yaitu Indonesia, Malaysia, dan Filipina (McKirdy, Quiano \& Watson, 2017). Untuk semakin meningkatkan efektifitas patroli tersebut, ketiga negara juga membangun pusat komando (Maritime Command Center) di masing-masing negara, dan meskipun patroli gabungan difokuskan di perbatasan wilayah perairan, akan tetapi aktivitas patroli gabungan juga menyertakan pengamanan di wilayah udara dan darat.

Perhatian serius terhadap wilayah perairan di perbatasan tiga negara tersebut, didasarkan pada fakta bahwa pergerakan kelompok teroris Negara Islam Irak dan Suriah di Asia Tenggara telah secara efektif memanfaatkan wilayah perbatasan perairan untuk menghimpun kekuatan. Ini dibuktikan dengan keberhasilan mereka memanfaatkan Selat Sulu sebagai jalan masuk untuk mengumpulkan para jihadis dari Indonesia dan Malaysia menuju pusat kekuatan 
kelompok ISIS di kawasan Asia Tenggara yakni di Filipina bagian selatan. Oleh karena itu, inisiatif Indonesia, Malaysia dan Filipina menyelenggarakan operasi pengamanan trilateral di wilayah tersebut menjadi sangat logis, mengingat ketiga negara tersebut memiliki garis pantai yang terhubung ke Selat Sulu. Untuk memberi gambaran lebih jelas mengenai Selat Sulu yang menjadi wilayah pergerakan para jihadis ISIS dari tiga negara di Asia tenggara tersebut, dapat dilihat pada Gambar 2.

\section{Gambar 2. Peta Pergerakan Jihadis ISIS di Asia Tenggara}

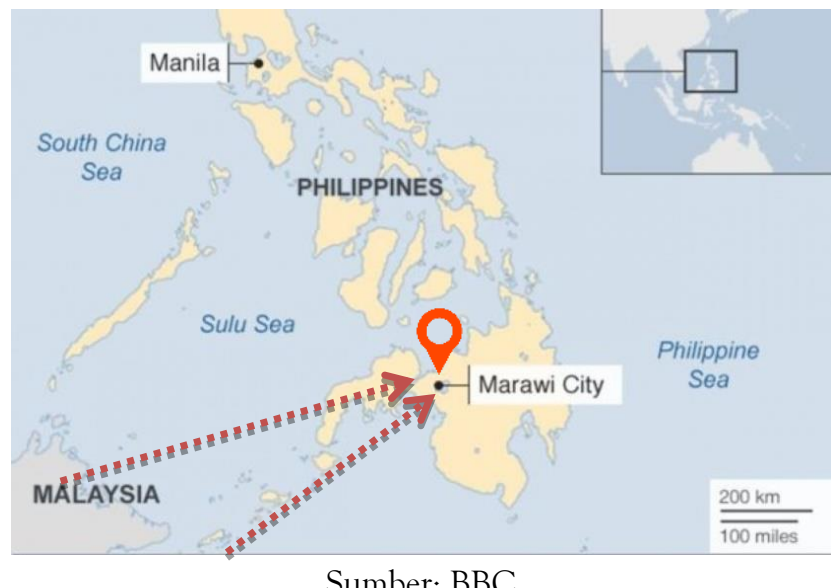

(Selat Sulu sebagai wilayah yang dimanfaatkan sebagai jalur pergerakan jihadis ISIS dari Indonesia dan Malaysia menuju pusat kekuatan di Marawi, Filipina Selatan)

Selanjutnya, Indonesia, sebagai negara terbesar di kawasan Asia Tenggara juga menawarkan mekanisme kerja sama intelijen kepada seluruh otoritas pertahanan negara ASEAN yang mengacu pada model kerja sama intelijen Amerika Serikat dan sekutunya. Kerja sama yang dinamai 'Our Eyes' tersebut oleh Menteri Pertahanan Indonesia, Ryamrizad Ryacudu, disebut sebagai mekanisme yang sangat dibutuhkan dan efektif untuk menangkal ancaman keamanan terorisme saat ini, karena ia berkeyakinan bahwa tidak ada satupun negara yang dapat menghadapi dan menyelesaikan tantangan ancaman non-tradisional tersebut secara mandiri (Santoso, 2017). Melalui mekanisme tersebut, pengawasan terhadap pergerakan kelompok terorisme di kawasan dilakukan dengan menukar informasi intelijen dari masing-masing negara anggota secara berkala, yakni melalui pertemuan rutin para petinggi otoritas keamanan setiap dua minggu sekali. Dalam perkembangannya, kerja sama intelijen yang diinisiasi oleh lima negara di ASEAN tersebut, telah ditanda tangani oleh seluruh anggota organisasi kawasan (The Straits Times, 2018). Meski dalam pelaksanaannya masih terdapat nuansa ketidakpercayaan di antara negara-negara anggota, akan tetapi terbentuknya kerja sama tersebut membuktikan adanya komitmen yang kuat di antara negara-negara di kawasan untuk mencegah semakin meluasnya ancaman terorisme, khususnya ancaman ISIS.

Sebenarnya, ketika isu terorisme global mulai menjadi perhatian negara-negara di dunia sejak era 1980-an, lebih lagi ketika beberapa kelompok terorisme mulai membangun basis kekuatannya di beberapa kawasan dengan kemampuan yang lebih spesifik, terutama dalam hal penguasaan senjata modern dan teknologi, negara-negara di Asia Tenggara telah menunjukkan respon serius dengan menyelenggarakan kerja sama di antara mereka untuk menghadapi ancaman tersebut. Misalnya, pada tahun 1997, para Menteri Dalam Negeri di kawasan telah membahas kesepakatan untuk meningkatkan pertukaran informasi dan data intelijen, mendorong seluruh anggota untuk meratifikasi konvensi internasional terkait penanganan terorisme, memanfaatkan organisasi yang lebih besar seperti ASEAN Regional Forum (ARF) dan ASIA-Pacific Economic Cooperation (APEC) untuk membangun inisiatif dan mekanisme terbaik dalam membagi informasi intelijen, serta berupaya berperan aktif meningkatkan koordinasi pada level internasional sebagaima yang dilakukan pada tahun 1999 dengan jalan menyusun perencanaan aksi dalam penanggulangan kejahatan lintas negara pada level nasional, regional maupun global (Djelantik, 2016: 193-194). 


\section{KESIMPULAN}

Meletusnya pertempuran di Marawi menjadi fakta yang mempertegas indikasi bahwa Asia Tenggara berpotensi menjadi tujuan baru bagi pejuang ISIS setelah proyek mendirikan kekhalifahan di Timur Tengah menghadapi perlawanan keras. Bergabungnya kelompok militan lokal seperti Abu Sayyaf dan kelompok Maute di bawah bendera hitam pimpinan Abu Bakar Al-Baghdadi, maupun eksistensi simpatisan individu ISIS yang tersebar di Indonesia, Malaysia, Filipina dan Singapura, juga turut memperbesar peluang bagi meluasnya ancaman ISIS di Asia Tenggara. Belum lagi, ancaman datangnya para jihadis dari luar kawasan (FTF) yang turut serta kembali bersama para jihadis dari Asia Tenggara dari Irak dan Suriah setelah mereka menderita kekalahan besar, semakin memperkuat anggapan bahwa Asia Tenggara merupakan kawasan potensial bagi ISIS untuk melanjutkan agenda mendirikan Negara Islam. Menghadapi ancaman tersebut, negara-negara di Asia Tenggara segera mengambil upaya sekuritisasi melalui peningkatan kerja sama keamanan kawasan.

Kesepakatan untuk melakukan pengawasan secara terpadu, baik dalam hal pengawasan persebaran jaringan teroris yang berafiliasi dengan ISIS, membagi informasi data intelijen sesama negara anggota maupun mitra di luar kawasan yang memiliki komitmen memberantas terorisme, aliran dana hingga pengawasan arus komunikasi berbasis jaringan internet, menjadi beberapa kebijakan yang diambil untuk menghadapi potensi ekspansi ISIS di Asia Tenggara, khususnya setelah serangkaian serangan bom dan berkibarnya bendera Negara Islam ISIS berkibar di Marawi.

Meski demikian, sejauh ini berbagai badan yang telah dibentuk melalui mekanisme organisasi kawasan dalam rangka menghadapi ancaman terorisme yang dibentuk hanya produktif di dalam melahirkan produk kebijakan, tetapi masih lemah dalam pelaksanaan, terutama yang dilaksanakan secara bersama karena sebagian negara masih mempertahankan serangkaian norma yang bersinggungan dengan upaya-upaya constructive intervention dan flexible engagement sebagai konsep yang jauh memiliki capaian keamanan yang lebih luas daripada sekedar urusan kedaulatan di tengah ancaman keamanan yang sudah melampaui batasanbatasan yang dipertahankan suatu negara (Luhulima, 2011: 254). Jika elit politik negara-negara di kawasan tidak segera menemukan konsensus bersama dalam menghadapi pergeseran lanskap keamanan di kawasan, bukan tidak mungkin di masa mendatang, upaya untuk membendung ancaman terorisme akan semakin sulit dicapai.

\section{CATATAN BELAKANG}

I Penggunaan istilah 'lone wolf' dalam konteks terorisme bertujuan untuk memberi perbedaan secara jelas terhadap aksi terorisme yang dilakukan oleh pelaku secara individual, termasuk di dalamnya subjek, motif dan tujuan yang secara jelas terpisah dari aktivitas yang dilakukan oleh kelompok jaringan, maupun organisasi teroris. Definisi istilah tersebut juga beragam. Misalnya, Burton dan Stewart memberi definisi bahwa 'lone wolf' adalah seseorang yang melakukan aksi (teror) secara mandiri tanpa perintah atau terhubung dengan suatu organisasi. Mereka menjalankan operasi dan memilih target dengan mengandalkan kemampuan pribadi (self-nature) serta dapat melakukan aksinya setiap waktu tanpa harus menunggu perintah dari kelompok atau organisasi. Lihat dalam Ramon Spaaij, Understanding Lone Wolf Terrorism: Global Pattern, Motivations and Prevention (London: Springer, 20 I2).

\section{REFERENSI}

Iraq: PM Abadi declares victory over ISIL in Fallujah,' Al Jazeera. (daring), 2016.

(http://www.aljazeera.com/news/2016/06/iraq-pmabadi-declares-victory-isil-fallujah-

| 606 17 174259486.html, diakses pada 27 November 2016).

'ISIS makin terdesak, Irak siap rebut Mosul dan Suriah kepung Palmyra.' 20।6. Kompas. (daring),

(http://internasional.kompas.com/read/2016/03/24/I 84 I 094 I/ISIS.Makin.Terdesak. Irak.Siap. Rebut.Mosul. dan.Suriah.Kepung.Palmyra, diakses pada 29 November 2016).

'Islamic State Leader Abu Muhammad al-Adani Killed In Airstrike, Pentagon Confirms.' 2016. Huffington Post. (daring), 
(http://www.huffingtonpost.com/entry/lslamic-stateal-adnani-killed_us_57d73c08e4b0fbd4b7bb3724, diakses pada 30 November 2016).

Alkhshali, H., Lister, T. \& Dewan, A. 2016. 'Libyan forces taking back ISIS stronghold,' CNN. (daring), (http://edition.cnn.com/20 16/06/I I/world/isis-libyasirte-offensive/index.html, diakses pada 27 November 2016).

Australia-Asean Kerja Sama Hentikan Aliran Dana Teroris. 2017. Sekretariat Nasional ASEAN. (daring). (http://setnas-asean.id/news-events/read/australiaasean-kerja-sama-hentikan-aliran-dana-teroris, diakses pada 28 Desember 2017).

Bacungan, VJ \& Jiao, Claire. 2017. ASEAN defense ministers call for stronger cooperations vs. terrorism. CNN Philippines. (daring).

(http://cnnphilippines.com/news/2017/10/24/aseandefense-ministers-meeting-cooperationterrorism.html, diakses pada 20 Desember 2017).

Buzan, B., Weaver, O. \& Wilde, J. dee. 1998. Security: A New Frameworks for Analysis. Boulder. Lynne Rienner Publisher.

Chalk, P. 20 I 5. Black flag rising: ISIL in Southeast Asia and Australia. Australia. Australian Strategy Policy Institute.

Davison, J. \& Said, R. 2017. Islamic Stated defeated in its Syrian capital Raqqa. Reuters. (daring),

(https://www.reuters.com/article/us-mideast-crisisSuriah-raqqa/Islamic-state-defeated-in-its-Suriahncapital-raqqa-idUSKBN I CMOVC diakses pada 25 Desember 2017).

Edwards, S. 2016. 'Is ISIS' presence in South-East Asia overstead?,' CNN. (daring),

(http://edition.cnn.com/20 I6/0 I/I 5/asia/indonesiaisis-south-east-asia/index.html, diakses pada 26 November 2016).

Fealy, G. 2017. The battle for Marawi and ISIS in Southeast Asia. Australian Strategic Policy Institute. Lihat dalam https://www.aspistrategist.org.au

Fonbuena, C. 2017. A Region In Panic: ASEAN double down against ISIS threat. Rappler. (daring). (https://www.rappler.com/newsbreak/indepth/I 887| 7-asean-terrorism-scare-isis-prevention, diakses pada 20 Desember 2017).

Hashim, A. S. 2015. The Impact of the Islamic State in Asia. Singapore. RSIS Policy Report.

Hubbard, B. \& Schmitt, E. 2017. ISIS, Despite Heavy Losses, Still Inspire Global Attacks. The New York Times. (daring),

(https://www.nytimes.com/20 17/07/08/world/middle east/isis-Suriah-iraq.html, diakses pada 25 Desember 2017).

Khan, Muqtedar. 20 I I. Terrorism and Globalization. Lihat dalam http://www.glocaleye.org/terglo.htm
Liow, J. C. 2016. 'Escalating ISIS threat in Southeast Asia: Is the Philippines a weak line?,' CNN. (daring), (http://edition.cnn.com/2016/07/07/opinions/isissoutheast-asia-liow/, diakses pada 26 November 2016).

Luhulima, C.P.F. 20 I I. Dinamika Asia Tenggara Menuju 20I5. Yogyakarta. Pustaka Pelajar.

Mackay, M. 20I 5. 'U.S.: ISIS loses quarter of territory in Iraq-3 things you need to know,' CNN. (daring), (http://edition.cnn.com/20 15/04//5/middleeast/isisloses-territory-iraq/index.html, diakses pada 27 November 2016).

McKirdy, Euan., Quiano, Kathy \& Watson, Ivan. 2017. CNN. (daring).

(https://edition.cnn.com/20 I7/06/19/asia/indonesiamalaysia-philippines-isis/index.html, diakses pada 28 Mei 2018)

Makinda, S. 2016. Terrorism in International Society: An Eclectic Perspective, Journal of Asian Security and International Affairs. Vol. 3 (I) 90- I01. Lihat dalam http://aia.sagepub.com DOI: 10.1 177/2347797015626053

Maresca, Thomas. 20 I6. ISIS expand foothold in Southeast Asia with Philipine siege. USA Today. (daring). (https://www.usatoday.com/story/news/world/2017/ 06/10/philippines-islamic-state-isis-southeastasia/I 02704672/, diakses pada 20 Desember 20 I7).

Maulana, V. 20I5. 'Ancaman ISIS di Asia Tenggara semakin besar,' SINDOnews.com. (daring), (http://international.sindonews.com/read/I068399/4 0/ancaman-isis-di-asia-tenggara-semakin-besar|449739785 >, diakses pada 3 Desember 20 |6).

Mortimer, C. 2016 . 'Isis loses a third of its territory in Suriah and Iraq, analysts say,' Independent. (daring), (http://www.independent.co.uk/news/world/middleeast/isis-territory-losing-Suriah-iraq-terror-jihadistsiraqi-forces-air-strikes-mosul-a735240 I.html, diakses pada 29 November 2016).

Osborne, S. 2016. 'ISIS ASIAN EXPANSION: Southeast Asia to become next jihadi base as terrorist expand EAST,' Express. (daring),

(http://www.express.co.uk/news/world/700489/ISISterror-southeast-asia-britons-holiday-thailand-jihadistourists, diakses pada 3 Desember 2016).

Pandey, A. 20I5. "ISIS Planning Attack In Southeast Asia Through Local Wing 'Katibah Nusantara': Report," IBT. (daring), http://www.ibtimes.com/isis-planningattacks-southeast-asia-through-local-wing-katibahnusantara-report-1943392, diakses pada 26 November 2016).

Pertemuan sub-regional 6 negara capai kesepakatan, rencana tindak lanjut, hadapi pergerakan ISIS. 2017. VOA Indonesia. (daring), (https://www.voaindonesia.com, Diakses pada 20 Desember 2017). 
Rogin, J. 2016. 'Islamic State Is Rapidly Expanding in Southeast Asia,' Bloomberg View. (daring), (http://originwww.bloombergview.com/articles/20 I 5-0529/Islamic-state-makes-a-move-on-southeast-asia, diakses pada 3 Desember 2016).

Santos, Ana P. \& Welle, D. 2017. Is Phillipines' Marawi free from ISIS influence? USA Today. (daring). (https://www.usatoday.com/story/news/world/2017/ 10/26/philippines-marawi-free-isisinfluence/80427900 I/, diakses pada 20 Desember 2017).

Santoso, Audrey. 2017. Hadapi Ancaman ISIS, RI Tawarkan 'Our Eyes' ke Menhan di ASEAN. Detiknews.com. (daring). (https://news.detik.com/berita/d3554925/hadapi-ancaman-isis-ri-tawarkan-our-eyeske-menhan-di-asean, diakses pada 20 Desember 2017).

Seib, P \& Janbek, D.M. 20I I. Global Terrorism and New Media: The Post-Al Qaeda Generation. Oxon. Routledge.
Spaaij, Ramon. 2012. Understanding Lone Wolf Terrorism: Global Pattern, Motivations and Prevention. London. Springer.

South-east Asian states launch intelligence-sharing pact to conter terror threat. The Straits Times. (daring). 2018. (https://www.straitstimes.com/asia/seasia/south-east-asian-states-launch-intelligence-pactto-counter-islamist-threat, diakses pada 26 Mei 2018).

Terrorism in Southeast Asia, Congressional Research Services, no. 7-5700, Washington, 2009

Westerman, Ashley. 2017. How Big A Threat Is Extrimism In Southeast Asia? Parallels. (daring).

(https://www.npr.org/sections/parallels/2017/06/I I/5 30949383/how-big-a-threat-is-extremism-insoutheast-asia, diakses pada 20 Desember 2017).

Winarno, B. 20I I. Isu-Isu Global Kontemporer. Yogyakarta. CAPS.

Yahya, Yamin. 2018. Asean and Australia signdeal to combat terrorism together. The Jakarta Post. (daring). (http://www.thejakartapost.com/seasia/2018/03/17/a sean-and-australia-sign-deal-to-combat-terrorismtogether.html, diakses pada 26 Mei 20।8). 